\title{
DEFINING HEALTH-RELATED QUALITY OF LIFE IN LOCALIZED AND ADVANCED STAGES OF BREAST CANCER - THE FIRST STEP TOWARDS HEREDITARY CANCER GENETIC COUNSELING
}

\author{
Tamara Žigman ${ }^{1}$, Ivana Lukša ${ }^{2}$, Gloria Mihaljević ${ }^{2}$ Maša Žarković \\ Iva Kirac ${ }^{1}$, Danko Velimir Vrdoljak ${ }^{1}$ and Ljiljana Šerman ${ }^{2}$ \\ ${ }^{1}$ University Hospital for Tumors, Sestre milosrdnice University Hospital Centre, Zagreb, Croatia; \\ ${ }^{2}$ University of Zagreb, School of Medicine, Zagreb, Croatia

\begin{abstract}
SUMMARY - The important goal in breast cancer treatment is to improve patient quality of life. Due to the huge economic burden, it is necessary to estimate the health state utility values for different breast cancer stages accurately. A group of 114 women filled out the EuroQol-5D-3L questionnaire at two time points. The participants were divided into three groups, as follows: group 1 including healthy high-risk individuals; group 2 including patients with localized stage breast cancer; and group 3 including patients with advanced stage breast cancer. Results were expressed either as summary health state utility score or summary visual-analog score. The EuroQol utility index score and EuroQol visual-analog score were statistically significantly higher in the group of healthy high-risk individuals. The EuroQol visual-analog score was mostly correlated with the anxiety/depression and pain/ discomfort quality of life dimensions. Health state utility values for different breast cancer stages are a necessary tool to perform economic analyses in breast cancer management decision making, due to its huge economic burden. Special attention should be paid to assessment of the psychosocial aspects of the disease, as well as pain management.
\end{abstract}

Key words: Breast cancer; Genetic counseling; Quality of life; Cost-benefit analysis

\section{Introduction}

Breast cancer is among the most common cancers in women and the second leading cause of cancer-related death in women ${ }^{1}$. It is estimated that one in eight (12.3\%) women will develop breast cancer during their lifetime. In 2012, 1,670,000 new cases of breast cancer were recorded worldwide. In Europe, nearly 460,000 women are affected every year ${ }^{2,3}$.

Despite available hormonal and targeted therapies, chemotherapy, improved surgical therapy and radio-

Correspondence to: Tamara Žigman, $M D, P h D$, Genetic Counseling Unit, University Hospital for Tumors, Sestre milosrdnice University Hospital Centre, Ilica 197, HR-10000 Zagreb, Croatia E-mail: tzarkovic@gmail.com

Received September 12, 2017, accepted September 27, 2017 therapy of breast cancer, 30\%-40\% of patients still develop metastatic disease. Locally advanced breast cancer, metastatic breast cancer, inflammatory breast cancer or breast cancer where curative surgical treatment or radiotherapy is not possible are considered advanced breast cancer stages ${ }^{4}$.

Patients diagnosed with breast cancer at an advanced stage are faced with a double burden, i.e. coping with significant adverse physical symptoms and with awareness that advanced stage breast cancer is a treatable but at long-term incurable disease. The success of the modern era of chemotherapy, targeted and hormonal breast cancer therapy has increased the number of patients with metastatic disease who receive several treatment modalities at the same time ${ }^{5}$. Having in mind that none of the advanced breast can- 
cer treatment modalities leads to permanent cure, the two main treatment goals are to prolong survival and to improve patient quality of life ${ }^{6}$. Assessment of these categories is becoming more important than the traditional treatment outcome measures, such as progression-free survival and overall survival ${ }^{7}$.

Quality of life has two main components, objective and subjective ones. Objective parameters such as personal income, health, education level and employment status are deficient indicators because they do not take into account the views and beliefs of the individual. Therefore, definition of the quality of life should take into account subjective parameters describing subjective reactions to different experiences ${ }^{8}$.

Cummins has described 7 domains of the subjective quality of life component, as follows: material well-being, health, productivity, intimacy, safety, place in society, and emotional well-being. He also explored the connection between the quality of life subjective and objective components and concludes that the correlation is low and has a non-linear character ${ }^{9,10}$.

There are several definitions in the literature that attempt to define this subjective concept ${ }^{11}$. The World Health Organization defines quality of life as the individuals' perception of their position in life in the context of the culture and value systems in which they live and in relation to their goals, expectations, standards and concerns ${ }^{12}$. Gotay et al. define quality of life as a state of well being, which consists of a person's ability to perform daily activities reflecting his/her physical, mental and social well-being and satisfaction with daily functioning and disease control $1^{13}$. Calman gives an interesting definition of the quality of life as a clash between the patient's expectations and achievements. The smaller the clash, the better is quality of life $^{14}$. Health-related quality of life (HRQoL) is a subjective assessment of health and welfare. It has been designated as a special term to emphasize the fact that this dimension is clearly distinguishable from other phenomena that contribute to better quality of life, such as income, freedom, or the environment ${ }^{15}$.

Due to inconsistency of the quality of life definition, there are many available instruments that measure quality of life with two basic approaches, i.e. generic instruments are multidimensional ones, developed to assess the general quality of life and specific instruments that measure quality of life in certain diseases. Generic instruments are widely used, particu- larly to determine demographic and cross-cultural differences in the quality of life ${ }^{16}$.

A quite often utilized and validated instrument from the group of generic instruments is EuroQol-5D (EQ-5D), which is used to assess health status for the purpose of health-economic analysis. It has been developed by the EuroQol Group in 1987 and used in numerous clinical trials, observational studies and research. EQ-5D is a standardized measure of health status developed as a simple, generic measure of health status for use in clinical and economic analysis. As it can be administered to a large number of diseases and types of treatment, this form is a simple descriptive profile of health status expressed as a 'utility index score' at the time of completion of the questionnaire. Cognitively undemanding, it is designed so as not to be time-consuming but easily filled out by the subject alone $^{17}$.

Quality of life estimated by the EQ-5D questionnaire is part of the Quality Adjusted Life Years (QALY) metrics, a term that incorporates life expectancy, as well as quality of life. It is used in health economics to determine priorities in redistribution of resources ${ }^{18}$.

The present study was conducted as part of the cost-effectiveness analysis of the implementation of hereditary cancer genetic counseling and testing program for the first time in Croatia. The aim of the study was to compare the HRQoL measured by EQ-5D questionnaire and expressed as EQutility index score (EQUS) or EQ visual-analog score (EQVAS) in localized and advanced stage breast cancer patients with healthy high-risk population. The second goal of the study was to investigate the dimensions of the questionnaire that mostly affect the quality of life expressed as VAS.

\section{Subjects and Methods}

The study was approved by the Central Ethics Committee, School of Medicine, University of Zagreb and Ethics Committee, Sestre milosrdnice University Hospital Centre, Zagreb. Participants were informed verbally and in writing about the purpose and methods of the study prior to giving their informed consent for participation and publication of the results.

The study was conducted at the Genetic Counseling Unit, University Hospital for Tumors, Sestre milosrd- 
nice University Hospital Centre from January 1, 2016 until December 31, 2016. Participation in the study was offered to all women having presented for genetic counseling during the mentioned period irrespective of age. The inclusion criteria were as follows: women diagnosed with breast cancer in any stage, and healthy women that were eligible for $B R C A 1 / 2$ gene genetic testing according to the recent National Comprehensive Cancer Network (NCCN) guidelines ${ }^{19}$. The questionnaire was offered at first consultation (first time point) and 3 months later (second time point). The exclusion criteria were as follows: men with breast cancer; women diagnosed with cancer other than breast cancer; and participants that failed to fill out the questionnaire completely and at both time points.

Out of 135 participants that were offered to fill out the questionnaire, 114 women were included in the study according to the inclusion criteria. They were divided into three groups: group 1 including healthy high-risk individuals; group 2 including patients with localized stage breast cancer; and group 3 including patients with advanced stage breast cancer. The group of high-risk subjects consisted of healthy women that were eligible for $B R C A 1 / 2$ gene genetic testing according to the recent NCCN Guidelines.

The participants filled out the questionnaire during their visit to the Genetic Counseling Unit at two time points, i.e. at the time of diagnosis of breast cancer in case of women diagnosed with breast cancer or at the time of first consultation in case of healthy women, and 3 months later.

\section{Instrument}

The first part of the questionnaire consists of 5 questions (i.e. EQ-5D descriptive system), each of them representing one of the 5 health state dimensions: mobility, self-care, usual activities, pain/discomfort and anxiety/depression. Each dimension has 3 levels: no problems, some problems, extreme problems. A total of 243 possible health states are defined in this way and converted to ED-5D utility index score using the time trade-off (TTO) valuation technique, ranging from -0.594 to 1.000 . For translation of EQ-5D3L scores into health utilities, we used the United Kingdom value set according to the EuroQol Group instructions. The health state described with negative utility index values is considered worse than death itself.
The second part of the questionnaire consists of EQ visual-analog scale (EQ VAS). The EQ VAS records the respondent's self-rated health on a vertical, visual analog scale where the endpoints are labeled "Best imaginable health state" and "Worst imaginable health state". This information is used as a quantitative measure ("Best imaginable health state" ranged as 100 and "Worst imaginable health state" ranged as 0) of health outcome as judged by the individual respondents. The participants filled out the questionnaire with the help of an experienced examiner.

\section{Statistical analysis}

Final EQUS and EQVAS were calculated as mean of the values obtained in the first and second time point. Mean value, standard deviation, median with minimum and maximum values were calculated for the EQUS and EQVAS for each group of patients.

Comparison of the groups was made using nonparametric Mann-Whitney test. To evaluate which of the five health state dimensions was mostly correlated to HRQoL expressed as EQVAS, we used linear regression model employing the stepwise backwards regression method. A p-value of 5\% was set as statistically significant. Statistical analysis was performed with the statistical tool R (http://www.r-project.org/).

\section{Results}

The total number of participants that met the inclusion criteria was 114 . The group of healthy highrisk individuals (group 1) consisted of 33 women, the group of patients with localized stage breast cancer (group 2) of 49 women, and the group of patients with advanced stage breast cancer (group 3) of 32 women.

Table 1 shows the EQUS and EQVAS measured in the first and second time point and overall EQ US and EQVAS expressed as mean, standard deviation, and median with minimum and maximum for each group of patients. The overall EQUS and EQ VAS were highest in the group of healthy high-risk individuals $(0.85)$ and lowest in the advanced stage breast cancer group (0.68). The EQUS was statistically significantly different between group 1 and group 2 $(\mathrm{p}=0.013)$ and between group 1 and group $3(\mathrm{p}=0.004)$. The EQ US was not statistically different between group 2 and group 3 ( $\mathrm{p}=0.469)$. 


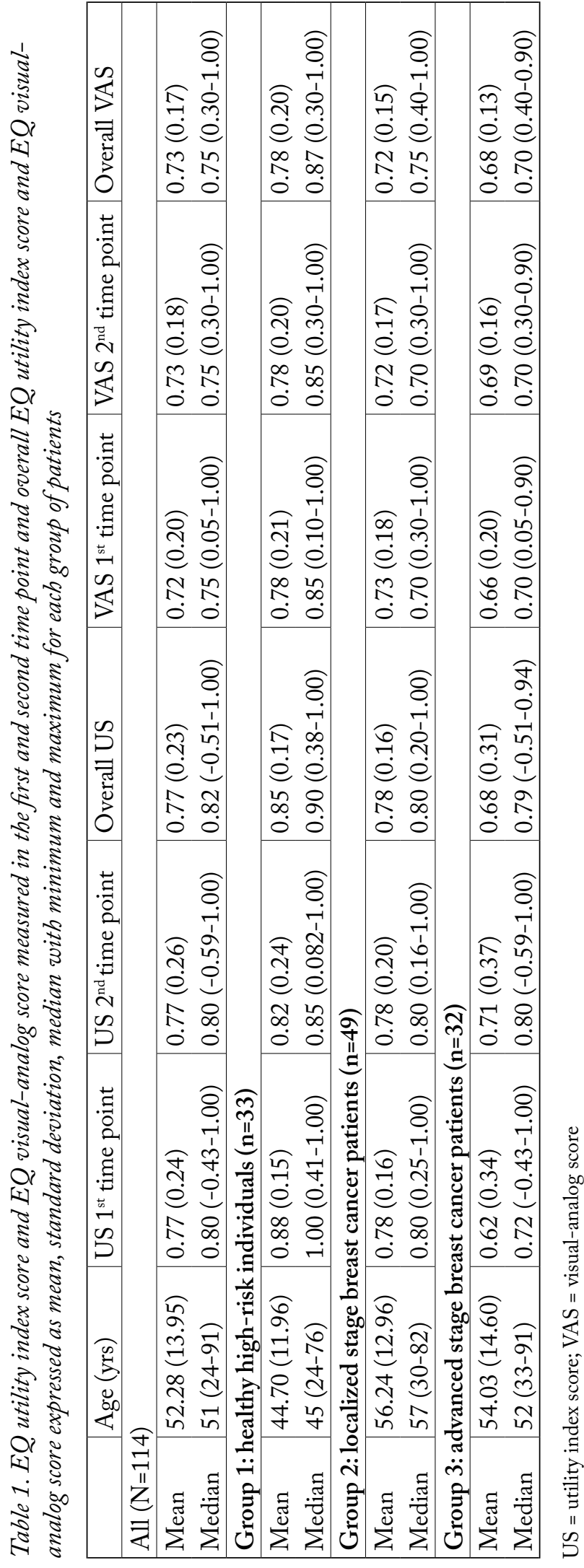

Table 2. Results of the linear regression model expressed as OR and 95\% CI for different levels of health state dimensions that were significant and incorporated in the final model

\begin{tabular}{|l|l|l|}
\hline VAS 1 $^{\text {st }}$ time point & OR & 95\% CI \\
\hline Mobility level 2 & 0.86 & $0.80-0.93$ \\
Mobility level 3 & 0.89 & $0.57-1.37$ \\
Pain/discomfort level 2 & 0.91 & $0.86-0.97$ \\
Pain/discomfort level 3 & 0.88 & $0.65-1.20$ \\
Anxiety/depression level 2 & 0.88 & $0.83-0.93$ \\
Anxiety/depression level 3 & 0.64 & $0.56-0.74$ \\
\hline VAS 2 ${ }^{\text {nd }}$ time point & OR & $\mathbf{9 5 \%}$ CI \\
\hline Mobility level 2 & 0.88 & $0.83-0.93$ \\
Mobility level 3 & 1.32 & $0.97-1.80$ \\
Pain/discomfort level 2 & 0.95 & $0.90-1.00$ \\
Pain/discomfort level 3 & 0.79 & $0.69-0.91$ \\
Anxiety/depression level 2 & 0.88 & $0.83-0.94$ \\
Anxiety/depression level 3 & 0.79 & $0.70-0.89$ \\
\hline
\end{tabular}

VAS = visual - analog score OR = odds ratio $; 95 \% \mathrm{CI}=95 \%$ confidence interval

Difference in EQVAS between group 1 and group 2 was at the border of statistical significance $(\mathrm{p}=0.055)$. The EQVAS was statistically significantly different between group 1 and group 3 ( $\mathrm{p}=0.006$ ). The EQVAS was not statistically different between group 2 and group 3 ( $\mathrm{p}=0.212)$.

Linear regression model using the stepwise backwards regression method was performed to evaluate which of the five health state dimensions mostly affected EQVAS. The results were calculated separately for EQVAS in each time point. The results of multivariate analysis are shown in Table 2 . The odds ratio (OR) for EQVAS in the first time point was lowest for the anxiety/depression level 3 (OR 0.64, 95\% CI $0.56-0.74)$. The EQVAS in the second time point was mostly correlated with the pain/discomfort level 3 (OR 0.79, 95\% CI 0.69-0.91), followed by anxiety/depression level 3 (OR 0.79, 95\% CI 0.71-0.89).

\section{Discussion}

Results of our study provided the health state utility values for localized and advanced breast cancer stages and compared them with the utility values of 
healthy high-risk individuals. The health state utility values were expressed as the mean value at three months of diagnosis. The health state utility values were highest in the group of healthy individuals and decreased in breast cancer patients according to the breast cancer stage. The VAS as a subjective indicator of the ndividual's health state was mostly influenced by the pain/discomfort and anxiety/depression score. It is impossible to reach the ideal health state utility value that accurately describes the health state in each breast cancer stage. Our approach was based on the fact that in the period of three months of the diagnosis patients usually experienced different psychological states (from disbelief to depression) and different treatment modalities (surgery, radiotherapy, chemotherapy) that could influence their quality of life $\mathrm{e}^{20}$. The summary health state utility value was obtained as a cross-section value during this period. The cross-section time approach allows measurements in a moderate number of study participants and gives a more accurate health state utility value than single measurement.

Comparing our results with the results from the study by Folse et al., we can conclude that the overall quality of life differed significantly in the healthy highrisk group (utility value 0.85 ) compared to healthy population (utility value 1.00 ). There is a possibility that this family burden puts an additional psychological burden that ultimately results in poorer quality of life $^{21}$. We assume that this additional psychological pressure could be facilitated by the genetic counseling process prior to genetic testing and afterwards, according to the study by Eijzenga et al..$^{22}$.

In our study, the health state utility values of localized and advanced breast cancer stage were similar to other reported studies ${ }^{23}$.

Our study additionally highlighted the importance of early psychological support and pain management during breast cancer treatment. Taking into account great progress in the development of various breast cancer therapeutic options in recent years, the society as a whole is facing new challenges. During and after the initial treatment, patients with breast cancer are faced with serious psychosocial issues such as personal and professional social disruption, depression, distress/ anxiety problems, fertility and sexuality doubts ${ }^{24}$. We are witnessing a period in which there is an increased number of breast cancer survivors and these psychoso- cial problems are even more pronounced in this group of patients. Breast cancer survivors are a vulnerable group with sometimes limited life expectancy. Younger breast cancer patients are prone to depressive disorders, and depression by itself could be an underdiagnosed state in older cancer patients. This raises a question of routine psychological assessment of breast cancer patients during treatment and afterwards. The idea of death and dying should be appropriately processed rather than avoided during the process of psychological counseling and patients should be empowered to reorder their life priorities ${ }^{25}$. One of the top clinical research needs in breast cancer is to increase efforts in survivorship research including supportive care and quality of life. The results of quality of life assessments in breast cancer patients are rarely used to guide clinical practice decisions ${ }^{26}$.

Assessing HRQoL is an important part of QALY metrics that has been widely used in economic analyses. QALY is a measure that is defined by the duration and quality of life that can be generated by health interventions. It represents the product of life expectancy and the health state utility value. QALY puts weight on the time spent in a particular health state. It is far away from the ideal outcome measure, with a number of shortcomings of technical and methodological nature. However, the use of QALY as an outcome measure that will guide the decision on redistribution of resources means that the choice between the two groups of patients that are competing for the same medical intervention is explicit, and that the groups are compared to the universal principle. In this way, the benefit that the health care system generates from new investments is transparent ${ }^{27}$.

The breast cancer economic burden is evident from the fact that treatment expenses will reach $\$ 157$ billion annually by 2020 , with an overall $27 \%$ increase in medical costs in the United States. The costs are highest for patients in the advanced stage. Having in mind this huge economic burden of breast cancer treatment and the need for economic analyses in the field, it is clear that it is necessary to estimate the health state utility values for different breast cancer stages as accurately as possible ${ }^{20,28}$. Additional studies are needed to explore the HRQoL in different breast cancer stages with special attention to psychological and pain issues. 


\section{Conclusion}

In conclusion, we can say that the health state utility values for different breast cancer stages are a necessary tool for performing economic analyses in breast cancer management decision making, due to its huge economic burden. Our paper for the first time brings the health state utility values expressed as time crosssection values for localized and advanced breast cancer stages, as well as for healthy high-risk population.

The results of our study showed the importance of anxiety/depression and pain/discomfort dimensions in the overall quality of life of breast cancer patients. Quality of life is an important treatment outcome and special attention has to be paid to the psychological burden of the disease, as well as to pain management.

Our study emphasized the importance of early psychological counseling in breast cancer patients and its implementation at the national level. The study was conducted as part of a cost-effectiveness analysis of the implementation of genetic counseling and testing program for hereditary breast cancer in Croatia. The results from this study will be used in further economic analysis.

\section{References}

1. Siegel RL, Miller KD, Jemal A. Cancer statistics. 2015. CA Cancer J Clin. 2015;65:5-29. doi: 10.3322/caac.21254

2. Ferlay J, et al. GLOBOCAN 2012 v1.0, Cancer Incidence and Mortality Worldwide: IARC CancerBase No. 11 [Internet]. Lyon, France: International Agency for Research on Cancer; 2013. Available from: http://globocan.iarc.fr: Accessed: 10 December 2016

3. Scalia-Wilbur J, Colins BL, Penson RT, et al. Breast cancer risk assessment: moving beyond BRCA1 and 2. Semin Radiat Oncol. 2016;26(1):3-8. doi: 10.1016/j.semradonc.2015.09.004

4. Tryfonidis K, Senkus E, Cardoso MJ, Cardoso F. Management of locally advanced breast cancer - perspectives and future directions. Nat Rev Clin Oncol. 2015;12:147-62. doi: 10.1038/ nrclinoc. 2015.13

5. Senkus E, Cardoso F, Pagani O. Time for more optimism in metastatic breast cancer? Cancer Treat Rev. 2014;40:220-8. doi: 10.1016/j.ctrv.2013.09.015

6. Smith I. Goals of treatment for patients with metastatic breast cancer. Semin Oncol. 2006;33(Suppl 2):S2-5. doi: 10.1053/j. seminoncol.2005.07.030

7. Ghislain I, Zikos E, Coens C, et al. Health-related quality of life in locally advanced and metastatic breast cancer: methodological and clinical issues in randomised controlled trials.
Lancet Oncol. 2016;17:e294-304. doi: 10.1016/S1470-2045 (16)30099-7

8. Germano D. Quality of Life and Sense of Coherence in People with Arthritis. Melbourne: School of Psychology, Faculty of Health and Behavioural Science, Deakin University (Burwood), 1996.

9. Cummins RA, ed. Comprehensive Quality of Life Scale for Adults (ComQol-4), $4^{\text {th }}$ edn. Melbourne: Deakin University, School of Psychology, 1993.

10. Cummins RA. Objective and subjective quality of life: an interactive model. Soc Indic Res. 2000;52:55-72. doi: 10.1023/ A:1007027822521

11. Bottomley A. The cancer patient and quality of life. Oncologist. 2002;7:120-5. doi: 10.1634/theoncologist.7-2-120

12. Development of the World Health Organization WHOQOLBREF quality of life assessment. The WHOQOL Group. Psychol Med. 1998;28:551-8. doi: 10.1017/s0033291798006667

13. Gotay CC, Korn EL, MyCabe MS, et al. Quality-of-life assessment in cancer treatment protocols: research issues in protocol development. J Natl Cancer Inst. 1992;84:575-9. doi: 10.1093/ jnci/84.8.575

14. Calman KC. Quality of life in cancer patients - a hypothesis. J Med Ethics. 1984;10:124-7. doi: 10.1136/jme.10.3.124

15. Guyatt GH, Feeny DH, Patrick DL. Measuring health-related quality of life. Ann Intern Med. 1993;118:622-9. doi: 10.7326/0003-4819-118-8-199304150-00009

16. Lynch HT, Watson P, Conway TA, et al. Clinical/genetic features in hereditary breast cancer. Breast Cancer Res Treat. 1990;15:63-71. doi: 10.1007/BF01810778

17. The Euroqol Group: http://www.euroqol.org/home.html: Accessed: 10 December 2016

18. EQ-5D-3L User Guide. Basic information on how to use the EQ-5D-3L instrument. Version 5.1. April 2015.

19. NCCN Guidelines. Genetic/Familial High-Risk Assessment: Breast and Ovarian. Version 1.2017, September 19, 2016. doi: 10.6004/jnccn.2017.0003

20. Reyes-Gibby CC, Anderson KO, Morrow PK, et al. Depressive symptoms and health-related quality of life in breast cancer survivors. J Womens Health. 2012 Mar;21(3):311-8. doi: 10.1089/jwh.2011.2852

21. Folse HJ, Green LE, Kress A, et al. Cost-effectiveness of a genetic test for breast cancer risk. Cancer Prev Res (Phila). 2013 Dec;6(12):1328-36. doi: 10.1158/1940-6207.CAPR-13-0056

22. Eijzenga W, Bleiker EMA, Hahn DEE, et al. Prevalence and detection of psychosocial problems in cancer genetic counseling. Fam Cancer. 2015;14:629-36. doi: 10.1007/s10689-0159809-9

23. Manchanda R, Legood R, Burnell M, et al. Cost-effectiveness of population screening for BRCA mutations in Ashkenazi Jewish women compared with family history-based testing. Natl Cancer Inst. 2014;107(1):380. doi: 10.1093/jnci/dju380 
24. Snyder C. Evolution of cancer risk assessment and counseling related to psychological, financial and legal implications. Fam Cancer. 2016;15(3):493-6. doi: 10.1007/s10689-016-9890-8

25. Di Lascio S, Pagani O. Is it time to address survivorship in advanced breast cancer? A review article. Breast. 2017;31:16772. doi: 10.1016/j.breast.2016.10.022

26. Cardoso F, Harbeck N, Barrios CH, et al. Research needs in breast cancer. Ann Oncol. 2017;28(2):208-17. doi: 10.1093/annonc/mdw571
27. Whitehead SJ, Shehzad A. Health outcomes in economic evaluation: the QALY and utilities. Br Med Bull. 2010;96:5-21. doi: 10.1093/bmb/ldq033

28. Vogt TM, Glass A, Glasgow RE, et al. The safety net: a costeffective approach to improving breast and cervical cancer screening. J Womens Health (Larchmt). 2003;12(8):789-98. doi: $10.1089 / 154099903322447756$

\section{Sažetak DEFINIRANJE KVALITETE ŽIVOTA
KOD BOLESNICA S LOKALIZIRANIM I UZNAPREDOVALIM STADIJEM RAKA DOJKE
- PRVI KORAK PREMA ONKOLOŠKOM GENETSKOM SAVJETOVANJU}

T. Žigman, I. Lukša, G. Mihaljević, M. Žarkovic, I. Kirac, D. V. Vrdoljak i Lj. Šerman

Važan cilj u liječenju raka dojke je poboljšanje kvalitete života bolesnica. Zbog velikog financijskog opterećenja važno je točno procijeniti parametre kvalitete života (engl. health state utility values) za različite stadije raka dojke. Skupina od 114 žena ispunila je upitnik EuroQol-5D-3L u dvije vremenske točke. Sudionice su podijeljene u 3 skupine: 1. skupina - zdrave visokorizične osobe; 2 . skupina - bolesnice s lokaliziranim stadijem raka dojke i 3. skupina - bolesnice u uznapredovalom stadiju raka dojke. Rezultati su predočeni ili kao sveukupni indeks kvalitete života bolesnica (engl. summary health state utility score) ili kao rezultat na vizualno-analognoj ljestvici (engl. summary visual-analog score). EuroQol utility index score i EuroQol visual-analog score bili su statistički značajno viši u skupini zdravih visokorizičnih osoba. Utvrđeno je da EuroQol visual-ana$\log$ score korelira sa sljedećim dimenzijama kvalitete života: anksioznost/depresija i bol/nelagoda. Parametri kvalitete života (engl. health state utility values) za različite stadije raka dojke važan su alat za provođenje ekonomske analize pri donošenju odluka o liječenju raka dojke, prvenstveno zbog velikog financijskog opterećenja. Osobitu pozornost trebalo bi usmjeriti na procjenu psihosocijalnih aspekata bolesti, kao i liječenju boli.

Ključne riječi: Rak dojke; Genetsko savjetovanje; Kvaliteta života; Analiza troškova i koristi 